2020, Vol. 9, Issue 1

Paweł Czubik*

\title{
POLISH CONSULAR LAW AND PRACTICE AFTER REGAINING INDEPENDENCE IN 1918 - THE SELECTED KEY ISSUES OF THE INTERWAR PERIOD
}

\begin{abstract}
The article discusses the selected issues of Polish consular law and practice in the period 1918-1939. The complicated interwar political situation had a direct impact on the practice of Polish consular offices. The consular relations with the Germans were particularly difficult. The enormous scale of the political problems in the Polish-German relations increased particularly during the years 1933-1939. The efficiency of consular intervention in favour of Polish citizens was insignificant. The relations with Soviet Russia were even more difficult. In the interwar period, Poland was the only country to have a consular convention signed with the Soviet state. The convention was considered to be very innovative with regard to immunities and privileges. However, the Soviets did not feel obligated by the treaties signed. As a result, Polish consuls and diplomats had no knowledge of the scale of the tragedy of the Polish population in the Soviet Union i.e. mass genocide committed by the NKVD in 1938. The exercise of consular functions, in this case, was practically impossible. The paper demonstrates that regardless of the difficult experiences with the neighbours, Poland after the rebirth of the statehood constructed a professional consular service, which performed its legal and supportive
\end{abstract}

* Associate Professor, the Head of the Department of International Public and European Law, Cracow University of Economics, Judge of the Supreme Court, Chamber of Extraordinary Control and Public Affairs, ORCID: 0000-0003-0268-8665. 
tasks. Consular functions were also successfully pursued by numerous Polish honorary consuls. International consular law explicitly provides the activity of honorary consuls. However, the performance of these activities depends on the consent of both interested parties - sending and receiving State. In the interwar period, this institution was very popular in international practice. It was practised simultaneously with the so-called 'etatisation' of honorary consulates. In Polish honorary consular offices, such a solution was very common. The article indicates that Polish law and consular practice in the interwar period was characterised by a modern approach to supportive and protective activities regarding the citizens. To a limited degree, Poland also provided consular activities for the citizens of the Free City of Danzig, which usually caused practical difficulties. Only exceptionally, the consuls would act for the citizens of other countries (in favorem tertii).

Keywords: Polish consular service in 1918-1939, honorary consuls, consular protection, consular activity in favorem tertii

\section{Introduction}

The birth of the Polish consular service preceded the rebirth of the Polish statehood after the 123 years of captivity. Already, the Polish centres of power, established during the World War with permission of the partitioning states and their allies, would gradually undertake protective tasks for the Polish population abroad. It was related to the care over the Polish soldiers from the Entente army, that were located in the Central Powers, as well as prisoners of war interned in POW camps. ${ }^{1}$ Such activities were mostly conducted for the purpose of freeing them from the camps, and enlisting them into the ranks of the Polish units allied with the Central Powers. Less often, such protection of a quasi-consular character would cover

1 The first consular functions for the Poles, during World War I were held by foreign delegacies of the Supreme National Committee, established in August 1914, acting for the transformation of the Austria-Hungary monarchy into an Austria-Hungary-Poland monarchy. See: J. Sibora, Narodziny polskiej dyplomacji u progu niepodległości [The birth of Polish diplomacy at the threshold of independence], Warszawa 1998, p. 103. The delegacies were then taken over by the Regency Council after it assumed the responsibilities of the Supreme National Committee. 
the civilians inhabiting neutral foreign countries, where the appropriate representation of the Polish authorities was established (the military recruitment was conducted in the neutral states as well, if possible). However, in time, with the decrease of the intensiveness of hostilities and the appearance of the actual chances for establishing an independent state, the activities of the resurgent state for the benefit of civilians would dominate the activities related to military affairs. The consular activities of supportive character therefore preceded the creation of the regular consular office of the reborn Poland. Formally, the quasi-consular office was established in 1917, both under the auspices of the Provisional Council of State (later the Regency Council) ${ }^{2}$ - allied with the Central Powers, and, with the beginning of 1918, under the auspices of the Paris-based Polish National Committee ${ }^{3}$ - allied to the Entente states. The former formed the base for the foreign service of the Second Polish Republic, but it also included the representatives of the latter one. ${ }^{4}$ Along with the reclamation of independence, the structures from the war period served as the basis for the consular service of the Second Polish Republic, which, since 1918, initiated active execution of its functions abroad.

2 The Regency Council established a professional Ministry of Foreign Affairs hereinafter referred to as the MSZ - (it was established on 26.10.1918, as a result of the transformation of the Department of Political Affairs, which was usually referred to as the Department of State - see: W. Komarnicki, Polskie prawo polityczne (geneza i system) [Polish political law (genesis and system)], Warszawa 1922, p. 47), including the Consular Department, from which the majority of the later consuls would originate.

3 A number of consular offices were established within the structures of the Polish National Committee, in various countries of the Entente. Often, their operations was financed by the contribution of the Polish diaspora.

4 This specific subordination of the consular offices to two centres of authority would formally function until April 1919. Then, the Polish National Committee was disbanded, while actually until the half of the 1919 the headship of the Committee would consult the consular nominations and the procedural matters related to the functioning of the consulates in the Entente territories, with the MSZ of the Polish Republic. See: W. Skóra, Stużba konsularna Drugiej Rzeczypospolitej. Organizacja, kadry, działalność [Consular Service of the Second Republic. Organisation, staff, activities], Toruń 2006, p. 11. 


\section{The source basis of the Polish consular law and practice}

The consular practice existing during the Great War period, without a doubt contributed to the shaping of the rather unique norms of consular law during the $20^{\text {th }}$ century - both regarding the norms of the internal law as well as the norms of bilateral conventions. Generally speaking, the countries that were newly created from the remains of the empires had the chance of creating new constructs that were not based on existing regulations. In the case of Poland which emerged from the ruins of three empires and comprised even five different legal systems, ${ }^{5}$ the necessity of a swift creation of new forms of the public law was especially urgent. Simultaneously, in 1918, Poland could not base its legal solutions on her own experience. Almost one-and-a-half century period since the first partition erased the preceding period from the social memory, which, in terms of consular relationships, was not abundant in source materials - the First Polish Republic (Polish-Lithuanian Commonwealth), in its history, was straying from the formalisation of contacts with the foreign countries and would not provide the presence of professional consuls, characteristic of the countries of the time. ${ }^{6}$ The dependent puppet states, existing temporarily within the territories of the former Commonwealth during the partition period did not pursue any foreign policy. ${ }^{7}$

5 Within the civil law framework, in the territories of the unified state, a number of different legal systems were applicable, including the Prussian, Russian, the so-called Russo-French (within the Kingdom of Poland territories), Austrian, and the Hungarian law in a small territory of Spisz and Orawa - regions partly adjoined to Poland.

${ }^{6}$ Only during the rule of the last Polish King Stanisław August Poniatowski, efforts were made to commission a professional (for its time) consular service. See: J. Sutor, Prawo dyplomatyczne i konsularne [Diplomatic and consular law], ed. XI, Warszawa 2010, p. 412, n. 6 . Before the partitions, no own, traditional consular solutions could be perpetuated. See: S.E. Nahlik, Narodziny nowożytnej dyplomacji [The birth of modern diplomacy], Wrocław 1971, p. 69 et seq.

7 Such legal opportunity existed only in the case of the Kingdom of Poland - a rump dependent state under the Russian rule, acknowledged at the Congress of Vienna in 1815. Despite the efforts taken at the time, due to the negative attitude of not only Russia but also Prussia, they brought no success (see: e.g. W. Zajewski, Dyplomacja polska w latach 1795-1831 [Polish diplomacy in 1795-1831], [in:] G. Labuda, W. Michowicz (eds.), 'Historia dyplomacji polskiej X-XX w.' [History of Polish diplomacy of the X-XX century], Warszawa 2002, p. 332). The Duchy of Warsaw, established by Napoleon in 1807 had no such formal opportunities. See: L. Mażewski, Księstwo Warszawskie i Królestwo Polskie z punktu widzenia prawa międzynarodowego [The Duchy of Warsaw and the Kingdom of 
In the first years after 1918, in view of the fact that the state borders were not shaped completely, local border wars and the war against the Bolsheviks (which ended with signing the peace treaty in Riga, on 18.3. $1921^{8}$ ), the situation was not conducive to the shaping and treatybased regulation of the consular service, nor for defining the internal law solutions regarding it. The basic tasks of foreign service, including consuls, were political - the essential matter was to secure the international recognition and the perpetuation of the position of Poland achieved in international relations. The victorious war against the Soviets and the aforementioned peace of Riga ${ }^{9}$ entailed stability of the country. Poland could therefore pay much more attention to the shape and the hierarchic position of the norms of internal law regarding foreign service, as well as to signing treaties executed in peace conditions.

While in terms of the private law rules, applying the law systems of partition states after regaining independence was possible until a deliberate codification of a common, nationwide legal system, ${ }^{10}$ for the systems of public law, including the rules referring to the function of foreign service, it was imperative to adopt own solutions swiftly. Therefore, at first the authorities applied legal acts of lower rank, enacted at the level of the

Poland from the perspective of international law], 'Państwo i Prawo' 2014, no. 2, pp. 62, 64 and 66.

8 The peace treaty between Poland, Russian and Ukraine, signed in Riga on 18.3.1921 (Polish OJ 1921, no. 49, item 300).

9 Regardless of the negative evaluation of the peace, which included numerous concessions of the Polish party as a state which had won the war, leaving territories that were (to a substantial degree) inhabited by ethnic Poles within the borders of the USSR (particularly the shameful passing of Lithuanian Minsk and Minsk territories over to the Soviets), and was de facto an act of treason against the Ukrainian plans of a federate state and the allied troops of Symon Petliura.

10 Poland accepted such an option. Decisions were made to keep the partition systems, and therefore, maintain the legal fragmentation, and gradually create a Poland's own legal system, by means of codification works (the codification commission, which was specific to Poland, was established by an act ratified by the Legislative Sejm in the half of 1919 - see: Law of 3.6.1919 on the Codification Commission, Polish OJ, no. 44, item 315). At the time, it was not an obvious attitude. Czechoslovakia or Yugoslavia acted entirely differently during the interwar period, as they expanded the rule of the Austrian law (at the moment of the establishment of a state, that would be effective in only one part of the territory) on the entire state territory. See: A. Dziadzio, Austriacki kodeks cywilny ABGB na ziemiach polskich w XX wieku [Austrian Civil Code ABGB in Poland in the $20^{\text {th }}$ century], [in:] J. Malec, W. Uruszczak (eds.), 'Ustrój i prawo w przeszłości dalszej i bliższej' [The system and law in the distant and close past], Kraków 2001, pp. 501-503. 
Ministry of Foreign Affairs, ${ }^{11}$ in order to move on to statutory regulations after a few years. There was no excessive hurry during the process, ${ }^{12}$ allowing to adopt a well-designed solution. The Polish consular act ${ }^{13}$ adopted in 1924 turned out to be innovative, and it contained an number of protective provisions that were not present within the consular regulations of other countries, adopted mostly at the end of the $19^{\text {th }}$ century. ${ }^{14}$

At the same time, the Polish Republic was entering into bilateral consular conventions rather actively, and they were characterised by innovative solutions. The solutions regarding consular functions were particularly essential. The previous treaty regulations generally focused on the matters related to the legal position of a consul - his privileges and immunities. The predominance of the regulations regarding consular privileges over the regulations regarding consular functions was already clear in treaties concluded by numerous countries before World War I, is slowly diminishing in favour of the state of equilibrium between the matters of functions and the immunity. In the interwar period, the Republic of Poland entered into 11 treaties ${ }^{15}$ referred to as Consular Conventions (with one treaty - with Turkey, failed to become effective due to the outbreak of World War II). Furthermore, two treaties on friendship, trade and sailing were established. ${ }^{16}$ Some of the legal aspects of consular affairs would also be affected by agreements on legal transactions (currently referred to as agreements on legal aid), that were signed with 6 entities by Poland during

11 It was not a practice that would be ruled out from the legal viewpoint. A number of countries regulates the functioning of their own foreign service only at the level of executive decrees of the Ministry of Foreign Affairs.

12 One should admit that accepting this solution on a legislative level was not a state priority, as the consular structures functioned properly without these regulations.

13 The 11.11.1924 law on the organisation of consulates and the activities of the consuls (Polish OJ 1924, no. 103, item 944).

14 See: e.g. the German law: Gesetz, betreffend die Organisation der Bundeskonsulate, sowie die Amtsrechte und Pflichten der Bundeskonsuln, Bundesgesetzblatt des Norddeutschen Bundes Band 1867, No. 11, Seite 137-156. In the process of consular tasks defined in the act (in the interwar period, related to the activities of the German consuls) there is not even a single general regulation that would address the protection of the citizens. On the other hand, such lack of regulation did not impede activities based on the international customary law (e.g. in the matter of protecting minorities).

15 Consular conventions were signed with: Latvia, Estonia, France, Hungary, Belgium, the Soviet Union, Italy, Romania, Bulgaria, Yugoslavia, and Turkey.

16 With USA and China. 
the interwar period. ${ }^{17}$ Polish consular relationships with the majority of countries were based solely on the norms of customary law (which, in terms of consular function, to this day ${ }^{18}$ remains the primary source of iuris gentium ${ }^{19}$ ).

In practice, the enormous role in the functioning of the Polish consular service was played by two key institutions: congresses and conferences, as well as consular circulars (instructions). The former were a natural, raw practical formula of modus vivendi in the conditions of the lack of detailed regulations referring to the consular law in the first years of the functioning of the Polish consular service, while later on their organisation was the object of the regulations by a circular. ${ }^{20}$ During the congress proceedings, the consuls of a given region of the world would unify the practice ${ }^{21}$ so that the party using the services of a consul of the Republic of Poland could be treated by each consul of the Republic in the same way. Regarding the difference of the essential legal issues, in various host countries attempts

17 During the interwar period, the Republic entered into such agreements with Austria, Czechoslovakia, Germany, the Free City of Danzig, Yugoslavia and Romania.

18 This is due to the fact that the Vienna Convention on consular relations of 1963 does not really regulate the issues of consular functions. The European convention on consular functions of 1967 is effective for a few countries, while countries usually establish bilateral consular conventions, essentially referring to consular functions, with some, a few dozen at most, foreign partners.

19 See: P. Czubik, K. Żółkiewicz, Matematyczne ustalenie zakresu obowiązywania międzynarodowego prawa umownego i zwyczajowego [Mathematical determination of the scope of international contractual and customary law], 'Problemy Współczesnego Prawa Międzynarodowego, Europejskiego i Porównawczego' 2011, vol. IX, pp. 215-223.

20 Official Gazette of Polish Foreign Affairs Office of 5.10.1922, no. 22, Year II, item 177. In accordance with the circular (pt. 1) the congresses should be held once a year (in Autumn or Winter), and their organisation would be entrusted to the accredited representative in a given countries, or if the region involved in one congress comprises more than one country - to the representative to a country containing the largest number of Polish consular offices (pt. 2) The congresses would usually be organised in the capital city of a given country, unless the transportation to a different location would be more convenient for the majority of the consular establishments (pt. 3).

21 See: the Minutes from the proceedings of the first convention of the Polish consuls to Balkan countries, Bucharest 11-13.3.1923, the Archives of Modern Records (Archiwum Akt Nowych, hereinafter referred to as: AAN), the Embassy in Bucharest, ref. no. 530, pp. 74-114, reprint [in:] H. Chałupczak, E. Kołodziej, M. Willaume (eds.), 'Zjazdy i konferencje konsulów polskich w Rumunii w okresie międzywojennym. Protokoły i referaty' [Congresses and conferences of Polish consuls in Romania in the interwar period. Protocols and papers], Lublin 2010, p. 38. 
were made to limit the congresses solely to the consuls of various consular regions of the same host country (or to no more than a few countries of the region).

The circulars essentially regulated all the issues related to the exercise of the consular functions, and even to the means of using the facilitations and privileges given to the consuls by the host countries. The circulars were both official instruction of a high degree of abstraction and generalisation of their norms as well as a list of highly detailed and individual decisions. The circular was the first basis for the functioning of the independent consular service of the reborn Poland ${ }^{22}$ and, interestingly, as the means of regulating the consular issues it had not lost significance with the adoption of the consular act of 1924. The act itself, being modelled after the acts of other countries of the period, with a lapidary character, low level of detail of the norms, allowed in Article 2 for issuing circulars by the Ministry of Foreign Affairs to the consuls (referred to as 'particular directive instructions and detailed orders'). The high degree of regulation of the consular practice with the issued circulars was characteristic of countries of the period. It had its own tradition ${ }^{23}$ coming from even medieval understanding of the instructions issued to the representative under ius legationis. ${ }^{24}$ The Polish attachment to circulars and instructions was primarily a result of using instructions in the Tsar's consular services ${ }^{25}$ that defined the means of

22 See: the Instruction regarding administrative activities, December 1918 a document from the Archives of Modern Records, Polish Foreign Affairs Office, ref. no. 11693, c. 9-11, reprint [in:] W. Skóra, 'Służba konsularna Drugiej Rzeczypospolitej'..., pp. 855-859. The author does not specify the exact date of publishing, while J. Sibora, Narodziny polskiej dyplomacji..., p. 257, points to 18.12 .1918 as the date of issue of four circulars by the Foreign Office Consular Department to regulate some consular issues (found in AAN, the Honorary Consulate in Zurich, ref. no. 72A, k. 1-6), including the cited instruction.

${ }^{23}$ Regarding the issuing of instructions by British consuls in the $18^{\text {th }}$ century, see: Ch.S. Kennedy, The American Consul. A History of the United States Consular Service, 1776-1924, (ed. II). Greenwood 2015, p. 4.

24 The genesis of the instructions and circulars should be seen in the instructions for representatives characteristic for the modern ius legationis. They were drawn up for a representative by the chancellor or the king. See: St.E. Nahlik, op. cit., p. 80 et seq. Cf. E. Satow, A Guide to Diplomatic Practice, London 1922, pp. 217-218.

25 Among the partitioning countries, the Poles could be seen in larger numbers only in the consular service of Austria (Austria-Hungary) - moreover, the estimates compared to the number of population of the Poles in the Habsburg Empire show that they were overrepresented - see: E. Deusch, Die effektiven Konsuln Österreich(-Ungarns) 
exercising consular functions in significant detail, reflecting the Russian practices. ${ }^{26}$

However, despite numerous detailed circulars and, at times, practical instructions for other Polish consuls accredited in the same host country, the consuls often had to decide on legal status, only based on whether the decision is just and equitable (the just nature of the issued decision). Such almost legislative, and not solely law-interpreting role of the consuls of the time constituted an element of the principles of the dynamics of the Polish foreign policy of the time. ${ }^{27}$

\section{Protective activities performed by consuls for Polish citizens abroad}

Based on experiences related to the activity of Polish officials providing consular protection for the citizens during World War I, particular attention in newly established treaties was paid to supportive activities of the consul

von 1825-1918. Ihre Ausbildung, Arbeitsverhältnisse und Biografen, Wien 2017, passim. Additionally, it resulted from the fact, that the Poles would often hold the highest government functions - Agenor M. Gołuchowski was the Minister of Foreign Affairs of Austria-Hungary (in 1895-1906), Alfred J. Potocki and Kazimierz Badeni - were the Prime Ministers of Austria (the former in 1870-1871, the latter in 1895-1897). However, the territories of the Russian partition were the dominating element of the country reborn in 1918, and the legal tradition based on that developed by Russian consuls, as fitting for the rules of the Russian civil law, effective in the prevailing portion of Poland, and in result, regulating the civil activities of the Polish consuls, turned out to be the dominant one.

26 Russian consuls received the first detailed and highly individualised - in regard to the host country - instructions in trade affairs in 1723. Since the half of the century, the process of their unification had been taking place. Due to the low level of precision of the consular act of 1903, included in the II Volume of the XI Digest of Laws (de facto being the amended text of the 1858 act), until the fall of the Tsars' Empire, there was a necessity for its creative interpretation, and specifying it with continuous circulars. See: Е.В. Сафронова, Становление и развитие консульской службы Российской Империи в XVIII-начале XX в., Санкт-Петербург 2002, pp. 69, 72-73, 76-78, 85, 131, 136, 143.

27 See: M. Kornat, Idee i podstawy polityki zagranicznej II Rzeczypospolitej [Ideas and foundations of foreign policy of the Second Republic of Poland], [in:] M. Kornat, W. Materski, 'Między pokojem a wojną. Szkice o dyplomacji polskiej lat 1918-1945' [Between peace and war. Sketches on Polish diplomacy from 1918-1945], Warszawa 2015, p. 28. 
for citizens. While, in the first accepted consular conventions (i.e. the agreement with Latvia, and the agreement with Estonia) there was no direct reference to the general citizen support activities, the later conventions of this sort would include such solutions. The consular conventions referred to the support of minors in particular. A special place was also taken by consular activities in maritime and succession-related matters - however, it was a standard solution in the case of the treaties signed at that time (as well as previous treaties signed by European countries - these activities would secure the financial profit of the sending nation).

Additionally, in the act on the organisation of consulates and the functions of the consuls of 1924, clear statements were made - being a unique solution in comparison to other regulations of the period - about the unambiguous responsibilities of the consul in terms of protecting the rights and interests of Polish citizens. ${ }^{28}$ The protective function regarding the citizens was not the priority of consular service of other countries at that time. The fact that the Polish case was different stems from the fact that, as it was previously mentioned, the service was born in the war conditions, when consular activities were focused on providing assistance to people who suffered during the war - it was easy to transform such prior tasks to the continuous care over the people in exile. Moreover, the reborn state attempted to persuade ethnic Poles scattered as a result of the historical events worldwide, to get back to the Polish soil. ${ }^{29}$

28 The Article 1 of the act already shows the clear responsibility for the protection of Polish citizens. Moreover, Article 15 of the consular act stated: 'The consuls are obligated to protect the rights and interests of Polish citizens, and to provide them with consultancy and support, observing the laws and the customs of the states, in which they hold office. The consuls are also obligated to watch over the fact, so that the Polish citizens are not impeded in enjoying their rights, concessions and privileges granted to them by local laws and customs, and by international agreements.' Apart from that, Article 20 was a special protective regulation, referring to permanent and seasonal migrants.

29 In order to assist in the migrant processes to Poland, the act of 20.1.1920 on Polish citizenship (Polish OJ 1920, no. 7, item 44) contained Article 3 holding a special criterion of the Polish origin, which, along with the statement of renouncement of foreign citizenship gave grounds to receive Polish citizenship. See: D. Malec, Obywatelstwo państwa polskiego w świetle orzecznictwa Najwyższego Trybunału Administracyjnego 19221939 [Citizenship of the Polish State in the light of the jurisprudence of the Supreme Administrative Court 1922-1939], 'Miscellanea Historico-Iuridica' 2015, vol. XIV, book 2, p. 81. 
The specificity of the Polish consular practice, appearing particularly (not solely though) in Polish-German relations, was the social protection of seasonal workers. The aforementioned issue was related to the mass scale of the phenomenon and the Polish-German agreement in this matter ${ }^{30}$ related to the economic migration of farming workers. The Polish consular act dedicated a separate Article 20 to the issue of migration (in practice, the economic one). ${ }^{31}$ Most often, the activities undertaken by the consuls for seasonal workers were of a nature of classic consular protection from violations of law against Polish citizens (including the labour law of the host state). ${ }^{32}$

The issues occurring in the 1930s in Poland (inter alia related to Ukrainian separatism) were amplified in consular districts abroad, forcing consuls to display very limited trust towards each holder of a Polish passport, as often (e.g. in Canada) the individual was hostile to Polish statehood and to Polish foreign service. Even in the countries where a vast number of Ukrainians with Polish passports resided, the consuls did not systemically reduce their support activities.

The protection of national, and even religious minorities, had characterised the diplomatic policies of countries for ages. The attempts to expand the jurisdiction of Christian countries on local Christians in the Orient, or the protection of the East Orthodox population in Turkey, to which the Russian authorities were aspiring, could be perceived as such. ${ }^{33}$ For obvious reasons, after World War I, due to the change of borders and the establishment of new countries, the issue of the protection of national

30 The Convention on the Polish Agricultural Workers between the Polish Republic and the German Reich (Polish OJ 1929, no. 44, item 366).

31 According to the regulation, the Polish consuls were to: 'pay special attention to the Polish permanent and seasonal migration within the territories of their responsibility, and to their re-emigration to Poland'.

32 See: J. Bestry, Stużba konsularna Drugiej Rzeczypospolitej w Czechosłowacji [Consular Service of the Second Republic in Czechoslovakia], Wrocław 2005, p. 163. Cf. Also E.J. Pałyga, Stosunki konsularne Drugiej Rzeczypospolitej [Consular relations of the Second Republic of Poland], Warszawa 1970, p. 39, n. 127.

33 One should also note the regulations of the Berlin treaty of 1878, which in Article 62 highlighted the traditional rights of France resulting from the previous Turkish obligations in regard to the former country (e.g. to the protection, by the consuls, of the Christians from those European states which did not have their own consuls in a given consular district). 
minorities had gained particular significance. ${ }^{34}$ Apart from protecting the economic interests of the Republic of Poland and the protection of Polish citizens, Article 1 of the Polish consular act of 1924 pointed to the 'watching over the execution of international agreements' as a responsibility of the consular. Without a doubt, the protection of the rights of minorities, guaranteed by the range of obligations related to the access of the state into the League of Nations, was an object of supervision by the Polish consuls, if in a given host state a Polish minority was present. However, it would not always be related to ensuring the non-discriminant standard of treating the minority.

Paradoxically, by providing protection to the citizens, which was a model one at the time, the Republic was not able to ensure even the minimum assistance to the Poles in the Soviet Union deprived of Polish citizenship. They were the descendants of the inhabitants of the PolishLithuanian Commonwealth, which due to the Peace of Riga were left on the other side of the border, ${ }^{35}$ where they were often (as in the vicinity of Lithuanian Minsk and Zhytomyr) the majority of residents. The amount of the Poles that remained within the USSR borders was estimated at approximately 1.5-2 million. As Soviet citizens, they were unable to receive

34 Additionally, one should admit that in the history of the $20^{\text {th }}$ century the NationalSocialist regimes would ruthlessly exploited the fact of the inhabitance of national minorities in neighbouring countries for their own aggressive purposes. The rhetoric of protecting the German minority and the supposed violation of its rights, was the essential part of the Nazi message, and contributed to the political eradication of Czechoslovakia.

35 However, one should note that from a legal point of view, the Peace of Riga would limit the repatriation of autochthonous Poles. Article VI, section 2, formally allowed to bring some individuals back to the country, i.e. the descendants of the participants of the independence efforts of 1830-1865, or individuals whose ancestors had lived within the territories of the former Commonwealth (not more than three generations back), that who understand and speak the Polish language and raise their children in the spirit of Polish nationhood. In practice, the Soviets allowed for no significant repatriation. See: R. Kuśnierz, Nas Polaków nie ma kto bronić... Represje wobec Polaków w Związku Sowieckim w latach 1935-1938 w materiałach MSZ i wywiadu wojskowego Drugiej Rzeczypospolitej [There is no one to defend us, Poles... Repressions against Poles in the Soviet Union in the years 1935-1938 in the materials of the Ministry of Foreign Affairs and military intelligence of the Second Republic of Poland], Warszawa 2018, passim. Additionally, the Republic displayed no will in the matter, as they feared, that with the acceptance of the Poles from Russia, the influx of Soviet agents to Poland would increase. 
any consular assistance from a formally foreign country, ${ }^{36}$ and the Soviets would practically disallow any particular rights of national minorities. In 1938, as a result of the 11.8 .1937 order no. 000485 issued by the head of NKVD as an element of the so-called NKVD's Polish Operation, at least 110.000 individuals of Polish origin were murdered, and 30.000 were deported to labour camps in Siberia. ${ }^{37}$

The execution of the anti-Polish operation in Russia was preceded by political actions from the Soviet part, during which the shutdown of a number of Polish and other Western European consulates was enforced. Therefore, information regarding the extermination would reach the RP consuls who held offices far from the Polish diaspora with significant delay, and the data lacked detail. The Republic knew about the persecution of the local Poles, but they did not have a clear image of the scale of the terrifying, mass genocide committed by the Soviets in 1938.

\section{The formal issues related to the consular relationships with Germany}

An essential practical problem that rankled the Polish border officials, was related to the application of exequatur in the relations with the Germans. It resulted from the particular treaty regulations, and also, very specific historical experiences of World War I. One should primarily highlight the intensity of mutual diplomatic relations, and the need for the mutual

36 During the period before gaining independence, and even during the first years of the functioning of the Second Polish Republic, the foreign service based its consular protection not on the citizenship (national affiliation) condition, but on their Polish ethnicity. It was understandable within the context of the creation of a new entity within the international law, as well as of the later agreements regarding Polish citizenship. See: C. Berezowski, Powstanie państwa polskiego w świetle prawa narodów [The creation of the Polish state in the light of the law of nations], Warszawa 1934, p. 343. Unfortunately for the Soviet Poles in the 1930, along with the solidification of the Polish State, the concept of citizenship gained a univocal meaning, and only this meaning of citizenship would make anyone eligible for the direct use of consular protection in Polish-Soviet relations.

37 See: M. Iwanow, Zapomniane Ludobójstwo. Polacy w państwie Stalina. 'Operacja polska' 1937-1938 [Forgotten Genocide. Poles in Stalin's country. 'Polish Operation' 1937--1938], Kraków 2015, passim. See also: W. Materski, Na widecie. II Rzeczpospolita wobec Sowietów 1918-1943 [At a vedette. The Second Republic towards the Soviets 1918-1943], Warszawa 2005, p. 485 et seq. 
guarantee of a dense network of consular offices. On both sides of the border, the population was ethnically mixed to a significant degree, moreover, as mentioned before, the seasonal migration of the contract workers from Poland to Germany was clearly visible. The consuls had to pay attention to the privileges of the citizens that were temporarily, or permanently residing in a host state, as well as to the legal status of the national minority. ${ }^{38}$

The intensity of Polish and German consular contacts can be dated back as early as to the World War I period. Polish officials were referred to as 'consuls without exequatur'. ${ }^{39}$ In time, the term had gained another meaning in the relations. According to Article 291 of the Treaty of Versailles, ${ }^{40}$ Germany was obligated to pass on to the countries of the Entente, along with the allied countries (this right was also exercised by the newly reborn Poland), the benefits resulting from all treaties signed by Germany with the future Central Powers before World War I. It was a construction of a most favoured nation clause from which the Germans quickly freed themselves, renouncing the treaties that would serve as the basis for particular benefits. ${ }^{41}$ Moreover, in regard to Germany, under Article 279, the Treaty of

38 What is worth mentioning - the enormous wealth of the union of the Polish national minority in Germany (including a bank, cooperatives, numerous commercial partnerships and companies as well as real estate - the value of which is currently estimated at approximately 35 million Euro) were taken over by the German state, under the Göring decree of 1940. Until this day, democratic German, has not abolished the consequences of this decree, therefore the Polish national minority, which has never stopped existing in Germany, has not regained its status (confirmed in the form of international agreements between Poland and the Third Reich before 1939 on numerous occasions), and the illegally stolen wealth was never returned.

39 See: A. Wasilewski, Polska służba konsularna 1918-1939 (akty prawne, organizacja, działalność) [Polish consular service 1918-1939 (legal acts, organisation, activities)], Torun 2004, p. 28 and further. Cf. M. Masnyk, Konsulat Generalny Rzeczpospolitej Polskiej w Bytomiu/Opolu wobec zagadnień organizacyjnych ruchu polskiego na Śląsku Opolskim [Consulate General of the Republic of Poland in Bytom/Opole in relation to the organizational issues of the Polish movement in Opole Silesia], [in:] R. Kaczmarek, M. Masnyk (eds.), 'Konsulaty na pograniczu polsko-niemieckim i polsko-czechosłowackim w latach 1918-1939' [Consulates on the German-Polish and Slovak-Polish border between 1918 and 1939], Katowice 2004, p. 43.

40 Polish OJ 1920, no. 35, item 200.

41 See: R. Gelles, Konsulaty we Wrocławiu [Consulates in Wrocław], Wrocław 1996, pp. 30-31; Cf. Z. Sarna, Zarys międzynarodowego prawa konsularnego ze szczególnem uwzględnieniem stosunków Polski [Outline of international consular law with particular emphasis on Poland's relations], Kraków 1928, pp. 53-60. Such uniquely beneficial 
Versailles granted the aforementioned countries the right to appoint consul without the necessity of submitting consular commission, nor receiving German exequatur. For Germany, the acceptance of this burden was highly problematic, and due to Germany's resistance, the countries would slowly withdraw from their privileges. Poland was among the first countries that challenged the sense of the Versailles privilege. The objections resulted from a number of issues. First, both the consular instructions, since 1918, as well as, the Polish consular act of 1924, assumed the necessity of receiving exequatur for the RP consuls. ${ }^{42}$ The practice, different in the case of the consuls in Germany, would introduce a peculiar administrative dissonance, Second, it was highlighted that performing the function without exequatur would be a departure from the international customs, which served as the basis for internal consular acts. ${ }^{43}$ In 1926, Poland officially renounced the privileges over Germany, and simultaneously, Germany granted exequatur to all Polish consuls. Interestingly enough, in the history of the Polish-German relationships during the interwar period, no cases of refusals of granting exequatur were recorded (probably being an object of prior, informal agreements), however, there were cases (including notorious ones ${ }^{44}$ ) of considering officials as persona non grata.

Additionally, it would be fitting to mention about the quite unpleasant consular activities, in which the Polish consular services participated during the last year before the war. As an effect of the activities of the Polish consuls, in result of the long-lasting disconnection from the state (a fact that was verified by the consular service, as to retain citizenship, one had to prove that he visited Poland within 5 years prior to the consular verification) tens of thousands people were deprived of their Polish citizenship. The aforementioned was a result of the execution of the

consular treaty, being the basis for privileges, by virtue of Article 291 of the Treaty of Versailles, was the German-Bulgarian consular convention of 1911.

42 Article 11 of the act clearly specified that the exequatur is a condition for the Polish consul's performance of the official functions.

43 See M. Szostakowska, Konsulaty polskie w Prusach Wschodnich w latach 1920-1939, Olsztyn 1990, p. 16.

44 For example, on 21.6.1939, a truly spectacular consideration of the RP consul in the formerly German Szczecin (W. Russocki) as persona non grata (it was told, that he should leave Germany within 48 hours). Even then, just before the war, the issue was solved with discretion, without publicity, or written notifications. See: W. Skóra, Konsulat RP w Szczecinie w latach 1925-1939. Powstanie i działalność [Polish Consulate in Szczecin in the years 1925-1939. Establishment and activity], Słupsk 2001, pp. 25-27, 58. 
regulation of the on the deprivation of citizenship of 31.3 .1938 act. $^{45}$ The deprivation significantly afflicted the Polish Jews that lived in Germany. Paradoxically, this fact sometimes saved their lives, which may have been planned by the Polish consular service. ${ }^{46}$ The protection over the Jews with Polish citizenship and living in the Third Reich after 1933 posed an enormous challenge for the Polish consular service. While formally racial discrimination could only afflict German Jews or stateless persons, the common criminal persecution against the Jewish population would also afflict individuals of this nationality, which possessed citizenship of other countries. The efficiency of consular intervention in this matter was insignificant. ${ }^{47}$ Jews deprived of Polish citizenship ${ }^{48}$ became stateless, and thus were deprived of any consular protection. The risk of such a state of affairs often motivated them to immediately leave Germany (most

45 Polish OJ 1938, no 22, item 191. Detailed information on the subject of the execution of this act by the Polish consular service, see: P. Czubik, Międzywojenne regulacje dotyczace utraty obywatelstwa polskiego, ich realizacja przez polskq służbę konsularna oraz znaczenie w procesie rozproszenia i emigracji diaspory Żydów polskich z III Rzeszy [Interwar regulations concerning the loss of Polish citizenship, their implementation by the Polish consular service and the importance of the diaspora of Polish Jews from the Third Reich in the process of dispersion and emigration], [in:] I. Głuszyńska, K. Lankosz (eds.), 'Państwo polskie wobec Polaków w diasporze' [Polish state towards Poles in the Diaspora], Bielsko-Biała 2013, pp. 213-223.

46 The consuls in Germany spoke quite openly that their task was to 'put off the Germans from the issue (...) so that they would enable them [i.e. the Jews] to leave overseas'. See: the minutes of the consular conference regarding the subject of the realisation of the act on the deprivation of the Polish citizenship, and on the visa policies, 24-25.5.1938 r., Archives of Modern Records, RP Embassy in Berlin, ref. no. 3278, pp. 119-136, 138-140, reprinted in H. Chałupczak, E. Kołodziej (eds.), Zjazdy i konferencje konsulów polskich w Niemczech. Protokoły i sprawozdania 1920-1939 [Congresses and conferences of Polish consuls in Germany. Protocols and reports 1920-1939], Lublin 1999, pp. 349, 354.

47 The Germans carried out mass deportation operations of the Polish Jews to the Polish-German border in October 1938, preceding the deprivation of these persons of the Polish citizenship (these operations, which were stopped by the Germans as a result of Polish protests, affected approximately 17 thousand people).

48 As shown in the source literature, as a result of applying this act by the consuls, until the half of April 1939, 'the Ministry of Foreign Affairs submitted 30133 requests for the deprivation of citizenship, regarding approximately 75 thousand people, including $88,1 \%$ of Jews' to the Ministry of Internal Affairs. See: G. Kulka, Nadawanie, pozbawianie i przywracanie obywatelstwa polskiego w czasie II wojny światowej [Granting, depriving and restoring Polish citizenship during World War II], 'Czasopismo Prawno-Historyczne' 2011, vol. LXIII, book 1, p. 150. Probably, a significant number of these requests were not executed before the war. 
frequently across the Atlantic Ocean) to essentially save their lives, if they had sufficient financial means. The Jews - Polish citizens who were not disconnected from Poland (in compliance with the act), and were not at risk of deprivation of Polish citizenship until $1939^{49}$ would remain in Germany and were practically all murdered by the Germans in concentration camps, following September 1939.

\section{The protective activities of Polish consuls provided in favorem tertii}

During the interwar period, particular legal relationships tied the Polish Republic with the Free City of Danzig. According to the Treaty of Versailles ${ }^{50}$ and the Paris Polish-Danzig convention ${ }^{51}$ to specify its provisions, the Republic of Poland would take the consular responsibilities for the Danzig citizens, and the Polish Treasury would be the only one to suffer the cost of this fact. ${ }^{52}$ However, in practice, the protective activities of the Polish consuls over the Danzig citizens abroad were not a rule by itself. First, the citizens of Danzig would usually not stamp their passports at the Polish Government Representative office, and the seal was a formal condition for the activity of the Polish consul abroad, for their protection. Moreover, without any legal ground, ${ }^{53}$ however, regularly since 1933, the German

49 The practical application of this act stopped already in Spring 1939, however it was formally cancelled by the Polish authorities in exile, by the decree of the President of Poland of 28.11.1941 on the repeal of the act of 31.3.1938 on the deprivation of citizenship (Polish OJ 1941, no. 8, item 22).

50 Polish OJ 1920, no. 35, item 200. See: Article 104, pt. 6 of the Treaty.

51 Polish OJ 1922, no. 13, item 117, see: Article 2 of the convention: 'Poland will take the responsibility of managing the Foreign Affairs of the Free City of Danzig, as well as the protection over Danzig citizens abroad. The protection will be provided on the same term as in the case of Polish citizens. The passports issued to Danzig citizens will ensure the Polish protection abroad, only if they will have a visa of the Polish Government Representative in Gdańsk'.

52 Article 5 of the Convention stated: 'The cost of the diplomatic and consular Representatives of the Free City of Danzig, as well as, the cost of the protection of its citizens abroad will be borne by Poland. All taxes and fees, charged by the diplomatic and consular service, will be payable to the Polish Government.'

53 As confirmed by the post-war judicial decision of the German courts (See: the decision of BGH of 14.1.1959, IV ZR 226/58, FJG, T. IV, p. 87). 
Reich had exercised protection over Danzig citizens. Additionally, the policy of the High Commissioner of the League of Nations was conducive to a certain independence of the foreign policy of the Free City, ${ }^{54}$ which, nolens volens, had to be accepted by Poland.$^{55}$ In practice the additional difficulties were caused by the lack of reference of certain consular conventions, in their literary wording, to the Free City of Danzig, ${ }^{56}$ and the possibility to assign Danzig officials to Polish consulates abroad (provided in Paris convention) was a troublesome solution (due to their mostly German ethnicity and espionage objectives). ${ }^{57}$

The protective activity conducted by the consuls of the reborn Republic in favorem of the citizens of other entities of international law during the interwar period, was a rare case. Some activities for citizens of Central Europe (Romania, Bulgaria, Yugoslavia, Hungary) were conducted by the

54 S. Mikos, Wolne Miasto Gdańsk a Liga Narodów 1920-1939 [The Free City of Gdańsk and the League of Nations 1920-1939], Gdańsk 1979, p. 123 et. seq.

55 However, one must stress that the principle was that Poland, as a hosting state, would treat Danzig as part of its territory. Therefore, issuing exequatur to consuls operating in Danzig, in agreement with the Senate of the Free City of Danzig, was adopted, however, in case when a consular district was to include both Danzig and a part of the Polish territory, Poland would issue only one exequatur independently. See: the procedure instructions on the acknowledgement of foreign country consuls in Poland and in the Free City of Danzig (doc. of 19.10.1934, Ministry for Foreign Affairs, no P.D.Kons.423/Zas/Exe/34) [reprint in:] K. Szwarcenberg-Czerny (ed.), Immunitety dyplomatyczne i konsularne. Zbiór norm prawnych z zakresu prawa międzynarodowego obowiqzzujacych na obszarze Polski i Wolnego Miasta Gdańska [Diplomatic and consular immunities. A collection of legal standards in the field of international law applicable in Poland and in the Free City of Gdańsk], Warszawa 1935, pp. 33-39. What is worth mentioning is that the agreements with Danzig regarding the exequatur were executed by Poland voluntarily - without treaty obligations on the matter. See: T. Joniec, Polska służba konsularna [Polish consular service], Warszawa 1996, p. 27.

56 The Polish consular act of 1924, in Article 27, clearly indicated, that its regulations are 'employed by the Free City of Danzig and the citizens of the Free City of Danzig within the framework of art. 104 of the Treaty of Versailles (...) and art. 2 of the Polish-Danzig convention signed in Paris on 9 November 1920.(...)'.

57 See: E.J. Pałyga, Stosunki konsularne..., p. 210-212. Regulation of the Article 3 of the Polish-Danzig Convention stated: 'In foreign cities, where the Free City of Danzig maintains serious economic interests, one or more citizens of the Free City of Danzig will be handed by the Free City at the disposal of the Polish Government, and will enter the composition of the Polish Consulates. These officials will be dependent on the Polish Government, and will be, under the direction and rule of the Polish Consul, dedicated to the matters regarding particularly the interests of the citizens of the Free City of Danzig'. 
Polish consuls in the Soviet Union of the 1920s - due to the objection of the Russians against their performance, they never took a formal shape. One exception was made by the Soviets in regard to France. In 1922, the USSR agreed for Poland to extend protection over the French citizens staying in Russia during their repatriation. ${ }^{58}$ In the interwar period, Poland was the only country to have a consular convention signed with the Soviet Russia (in 1924) - until 1939, the country would not sign any other consular conventions, with this sole exception. ${ }^{59}$

In 1924, Poland initiated protective and supportive activities for the Turkish citizens within the Territory of the Kingdom of Serbs, Croats, and Slovenes (Yugoslavia). The cause of the activities for this country was quite surprising. The accepted consular act did not include regulations that would allow consuls to perform juridical activities within the frameworks of the so-called capitulation jurisdiction. However, it included a blanket provision assuming the adoption of such an act in the future. ${ }^{60}$ However, it was never issued. Moreover, one should remember that during the First Republic, the unified Polish-Lithuanian Commonwealth did not use its rights to consular jurisdiction in the Orient. ${ }^{61}$ Such attitude was considered by Turkey as honourable, which caused the country to grant Poland a temporary diplomatic and consular protection of their citizens in the Balkans. ${ }^{62}$ One should note that the Polish colonial ambitions in the

58 See: A. Wasilewski, Polska służba konsularna..., p. 101.

59 The convention was considered to be very innovative, regarding immunities and privileges. See: A. Sudoł, Karol Poznański. Ostatni konsul generalny II Rzeczypospolitej. Zarys ważniejszych dokonań [Karol Poznański. Last Consul General of the Second Republic of Poland. Outline of major achievements], Bydgoszcz 1998, pp. 79-80.

60 Such announcement regarding the jurisdiction act in the unspecified future was included in the Article 24 of the act on the organisation of consulates and the activities of the consuls.

61 Such privileges for Poland, partially resulted from the Peace Treaty of Khotyn of 1621, giving the right (however not entirely executed) to maintain a permanent representation of the Commonwealth in Constantinopole (See: A. Przyboś, R. Żelewski, Dyplomaci $w$ dawnych czasach [Diplomats in the old days], Kraków 1959, pp. 37-39), and directly from Article VIII of the Treaty of Karłowice in 1699, which assumed the jurisdiction privileges regarding Polish merchants. On their basis, due to the lack of continuous consular service, the Commonwealth did not expand the capitulation jurisdiction in Turkey. See: J. Makowski, Prawo międzynarodowe [International law], Warszawa 1918, p. 285.

62 Turkey considered the attitude of the Polish foreign service as beneficial for the equality of the countries, in distinction from the attitude of other countries, who would 
interwar period were never as strong, or as politically grounded, ${ }^{63}$ to be able to result in any legal solutions in terms of consular jurisdiction.

\section{Honorary consuls}

An important role in the running consular affairs of the interwar period, was played by the employment of the honorary consul position. The Polish consular service of the period also employed this position. Due to the specific, non-professional character of such a consular official, the common practice was to establish a peculiar mixed agreement between the Polish State and the consul working on its behalf. From the viewpoint of internal law, the agreement was of a civil-law character (for providing services), with effect within the space of the international public law. Additionally, it regulated the financial issues, including the possible compensation for the costs of the functioning of the position borne by the consul. Due to the fact that the consuls had no power to execute legal or administrative action, by tradition a solution was applied of the so-called etatisation of honorary consulate - i.e. appointing a professional consular official to the consulate managed by the honorary consul, who was formally subordinated to the honorary consul, but retained a specific autonomy in executing his functions, and broader competence than the formal head of the consulate. At the time, the solution was a rule of the Polish and universal consular law, however, with time, after World War II, it started to decline, and now it only occurs sporadically. ${ }^{64}$ An essential consular rule, which, already at

continuously press on the expectations from the period before 1914, i.e. before the abolishment of the jurisdiction capitulations in the country. Many European countries would do so, not only ones with such a tradition, but also the countries that were newly established in 1918 (as, according to Turkey, e.g. Czechoslovakia). See D. Chmielowska, Polsko-tureckie stosunki dyplomatyczne w okresie międzywojennym [Polish-Turkish diplomatic relations in the interwar period], Warszawa 2006, p. 225.

${ }^{63}$ Although in the 1930s the Naval and Colonial League initiated private legal activities in Brazil and Liberia, in 1934, they ended with a fiasco, and most attempts regarding other territories, did not expand beyond the phase of theoretical arrangements.

64 Etatisation (with a single exception in the 1990s) was not applied after the resurrection of the position of honorary consul in Polish practice of the final years of the 1980s. See W. Staszewski, Konsul honorowy w prawie międzynarodowym i praktyce polskiej [Honorary consul in international law and Polish practice], Lublin 2018, p. 210 and further. See also M. Szymura, Instytucja konsula honorowego w praktyce konsularnej 
the time, was clearly distinguished, was for the sending state to confirm with the host state, by diplomatic means, or by own professional consul, that the candidate proposed for the position of a honorary consul would be granted exequatur. ${ }^{65}$ Such construction reminds of agrément acquired for a diplomat. It is commonly used to this day (it is possible to perceive it as a norm of the international customary law). ${ }^{6}$

\section{Summary}

Despite the exquisitely constructed regulations of internal law, and detailed bilateral treaty regulations that were in force with the countries that were the most important for Poland, the consular practice during the interwar period was not limited solely to the stable holding of office performed by Polish consuls. The complicated political situation had direct impact on the practice. The consular relations with the Germans were particularly difficult. Generally, despite the enormous scale of the political problems

Polski XX i XXI wieku [Institution of honorary consul in the consular practice of Poland of the $20^{\text {th }}$ and $21^{\text {st }}$ century], Opole 2009, pp. 108-109. Appointing professional officials to honorary consulates may cause protocol issues, and currently, is not preferred by various states.

65 See Referat Ambasady RP w Waszyngtonie na zjazd konsularny pt. Sieć konsulatów honorowych w Stanach Zjednoczonych, 10 lipca 1937, AAN, Konsulat Generalny RP w Nowym Jorku [The paper of the Polish Embassy in Washington for the consular convention entitled The Network of Honorary Consulates in the United States, July 10, 1937, AAN, Polish Consulate General in New York], sign. 339, pp. 135-144 [reprint in:] E. Kołodziej, T. Radzik (eds.), Zjazdy i konferencje konsulów polskich w USA i Kanadzie. Protokoły i referaty 1920-1938 [Congresses and conferences of Polish consuls in the USA and Canada. Protocols and papers 1920-1938], Lublin 2004, pp. 243-250.

66 See P. Czubik, M. Kowalski, Konsul honorowy. Studium prawnomiędzynarodowe [Honorary consul. International law study], Kraków 1999, p. 126. It is worth noting, that the few consular conventions in force, signed by Poland already after World War II, also implicate the necessity of receiving agrément before issuing a request for exequatur also for the professional consul. See e.g. Article 3(1) of the Consular Convention between the Government of the Polish People's Republic, and the Government of the Republic of Iraq, signed in Baghdad on 16.4.1980 (Polish OJ 1982, no. 27, item 194), which states: 'Before appointing the director of the consular office, the Sending State receives, through diplomatic means, the permission of the Hosting State, for this person'. The solution was not officially used in the conventions of the interwar period, neither is it a universal practice in the current consular relations between countries. 
in the Polish-German relations, which increased in intensity particularly in 1933-1939, as well as the gigantic, in comparison to other consular offices, scale of protective and supportive tasks of the Polish consuls in Germany, they performed their duties in an exemplary manner, to this day remaining as an unsurpassed model of consular service. The relations with the Soviet Russia, despite a unique convention regulation, were even more difficult. The Soviet state did not feel obligated by the treaties signed, the consuls would function in a 'golden cage', simultaneously, having no greater knowledge of the scale of the tragedy of the Polish population in the Soviet Union in the territories that belonged to the Commonwealth before 1772, but were not returned after 1918. The exercise of consular functions in this case was practically impossible.

Regardless of the difficult experiences with the neighbours, Poland managed to build a professional consular service in 1918-1939, which performed its legal (within the scope of iuris avocandi-i.e. primarily the administrative and civil law tasks) and supportive tasks (within the scope of the so called ius protectionis). The promotional activity, regarding economy and culture, was also successfully pursued by numerous honorary consuls. To a limited degree, Poland also provided consular activities for the citizens of the Free City of Danzig, which also caused practical difficulties. Sporadically, the consuls would act for the citizens of other countries. Polish law and consular practice was a modern approach to supportive and protective activities regarding the citizens. The experiences in this area, acquired by the consular service, during its development at the time of World War I, had to be used anew just 20 years later, in the circumstances of another world conflict, even more destructive for Poland. The outbreak of World War II, the simultaneous aggression of Germany and the Soviet Union, the betrayal by the French and English allies who, despite declaring war on Hitler, undertook no military action, forced the Polish authorities to go to exile. The foreign service, including consuls, did not stop their functions in neutral and allied states, contributing to the universal acknowledgement of the preservation of the subjectivity of Poland in the aspect of international law, despite its political territory being taken by the occupants. During World War II, the consuls of the Republic of Poland (including honorary consuls who worked with great devotion), using their actual capabilities and modest financial potential, once again primarily provided supportive and protective activities to the Polish citizens. 


\section{Bibliography}

1. Berezowski C., Powstanie państwa polskiego w świetle prawa narodów, Warszawa 1934

2. Bestry J., Służba konsularna Drugiej Rzeczypospolitej w Czechosłowacji, Wrocław 2005

3. Chałupczak H., Kołodziej E. (eds.), Zjazdy i konferencje konsulów polskich w Niemczech. Protokoły i sprawozdania 1920-1939, Lublin 1999

4. Chałupczak H., Kołodziej E., Willaume M. (eds.), Zjazdyi konferencje konsulów polskich w Rumunii w okresie międzywojennym. Protokoty i referaty, Lublin 2010

5. Chmielowska D., Polsko-tureckie stosunki dyplomatyczne $w$ okresie międzywojennym, Warszawa 2006

6. Czubik P., Międzywojenne regulacje dotyczace utraty obywatelstwa polskiego, ich realizacja przez polska służbę konsularną oraz znaczenie w procesie rozproszenia i emigracji diaspory Żydów polskich z III Rzeszy, [in:] Głuszyńska I., Lankosz K. (eds.), 'Państwo polskie wobec Polaków w diasporze', Bielsko-Biała 2013

7. Czubik P., Kowalski M., Konsul honorowy. Studium prawnomiędzynarodowe, Kraków 1999

8. Czubik P., Żółkiewicz K., Matematyczne ustalenie zakresu obowiązywania międzynarodowego prawa umownego i zwyczajowego, 'Problemy Współczesnego Prawa Międzynarodowego, Europejskiego i Porównawczego' 2011, vol. IX

9. Deusch E., Die effektiven Konsuln Österreich(-Ungarns) von 1825-1918. Ihre Ausbildung, Arbeitsverhältnisse und Biografen, Wien 2017

10. Dziadzio A., Austriacki kodeks cywilny ABGB na ziemiach polskich w XX wieku, [in:] Malec J., Uruszczak W. (eds.), 'Ustrój i prawo w przeszłości dalszej i bliższej', Kraków 2001

11. Gelles R., Konsulaty we Wrocławiu, Wrocław 1996

12. Iwanow M., Zapomniane Ludobójstwo. Polacy w państwie Stalina. „Operacja polska" 1937-1938, Kraków 2015

13. Joniec T., Polska służba konsularna, Warszawa 1996

14. Kennedy Ch.S., The American Consul. A History of the United States Consular Service, 1776-1924, (ed. II) Greenwood 2015

15. Kołodziej E., Radzik T. (eds.), Zjazdy i konferencje konsulów polskich w USA i Kanadzie. Protokoły i referaty 1920-1938, Lublin 2004

16. Komarnicki W., Polskie prawo polityczne (geneza i system), Warszawa 1922

17. Kornat M., Idee i podstawy polityki zagranicznej II Rzeczypospolitej, [in:] M. Kornat, W. Materski, 'Między pokojem a wojną. Szkice o dyplomacji polskiej lat 1918-1945', Warszawa 2015

18. Kulka G., Nadawanie, pozbawianie i przywracanie obywatelstwa polskiego w czasie II wojny światowej, 'Czasopismo Prawno-Historyczne' 2011, vol. LXIII, book 1

19. Kuśnierz R., Nas Polaków nie ma kto bronić... Represje wobec Polaków w Związku Sowieckim w latach 1935-1938 w materiałach MSZ i wywiadu wojskowego Drugiej Rzeczypospolitej, Warszawa 2018 
20. Malec D., Obywatelstwo państwa polskiego w świetle orzecznictwa Najwyższego Trybunału Administracyjnego 1922-1939, 'Miscellanea Historico-Iuridica' 2015, vol. XIV, book 2

21. Masnyk M., Konsulat Generalny Rzeczpospolitej Polskiej w Bytomiu/Opolu wobec zagadnień organizacyjnych ruchu polskiego na Ślasku Opolskim, [in:] R. Kaczmarek, M. Masnyk (eds.), 'Konsulaty na pograniczu polskoniemieckim i polsko-czechosłowackim w latach 1918-1939', Katowice 2004

22. Materski W., Na widecie. II Rzeczpospolita wobec Sowietów 1918-1943, Warszawa 2005

23. Makowski J., Prawo międzynarodowe, Warszawa 1918

24. Mażewski L., Księstwo Warszawskie i Królestwo Polskie z punktu widzenia prawa międzynarodowego, 'Państwo i Prawo' 2014, no. 2

25. Mikos S., Wolne Miasto Gdańsk a Liga Narodów 1920-1939, Gdańsk 1979

26. Nahlik S.E., Narodziny nowożytnej dyplomacji, Wrocław 1971

27. Pałyga E.J., Stosunki konsularne Drugiej Rzeczypospolitej, Warszawa 1970

28. Przyboś A., Żelewski R., Dyplomaci w dawnych czasach, Kraków 1959

29. Сафронова Е.В., Становление и развитие консульской службы Российской Империи в XVIII-начале XX в., Санкт-Петербург 2002

30. Sarna Z., Zarys międzynarodowego prawa konsularnego ze szczególnem uwzględnieniem stosunków Polski, Kraków 1928

31. Satow E., A Guide to Diplomatic Practice, London 1922

32. Sibora J., Narodziny polskiej dyplomacji u progu niepodległości, Warszawa 1998

33. Skóra W., Konsulat RP w Szczecinie w latach 1925-1939. Powstanie i działalność, Słupsk 2001

34. Skóra W., Służba konsularna Drugiej Rzeczypospolitej. Organizacja, kadry, działalność, Torun 2006

35. Staszewski W., Konsul honorowy w prawie międzynarodowym i praktyce polskiej, Lublin 2018

36. Sudoł A., Karol Poznański. Ostatni konsul generalny II Rzeczypospolitej. Zarys ważniejszych dokonań, Bydgoszcz 1998

37. Sutor J., Prawo dyplomatyczne i konsularne, ed. XI, Warszawa 2010

38. Szostakowska M., Konsulaty polskie w Prusach Wschodnich w latach 1920-1939, Olsztyn 1990

39. Szwarcenberg-Czerny K. (ed.), Immunitety dyplomatyczne i konsularne. Zbiór norm prawnych z zakresu prawa międzynarodowego obowiązujących na obszarze Polski i Wolnego Miasta Gdańska, Warszawa 1935

40. Szymura M., Instytucja konsula honorowego w praktyce konsularnej Polski XX i XXI wieku, Opole 2009

41. Wasilewski A., Polska służba konsularna 1918-1939 (akty prawne, organizacja, działalność), Torun 2004

42. Zajewski W., Dyplomacja polska w latach 1795-1831, [in:] G. Labuda, W.Michowicz (eds.), 'Historia dyplomacji polskiej X-XX w.', Warszawa 2002 